\title{
MAKE IN INDIA AND SUSTAINABLE INDUSTRIAL DEVELOPMENT
}

\author{
Naib Singh ${ }^{1 *}$ \\ *1Assistant Professor, Deptt. of Commerce, Rajiv Gandhi Govt. College, Saha-(Haryana)
}

*Corresponding Author: -

\begin{abstract}
: -
Indian economy is attaining the development at very rapid rate. India has the position as one of the fastest developing nations with higher Gross Domestic Products (GDP). Industries of India are contributing towards the GDP up to 28 percent. Industrial Policy is the main factor for the rapid development of the economy. Developing countries require any definite industrial supportive measure for combating many evils which are affecting the development adversely. For the sustainable development of the industrial sector we have to maintain as well as increase this share by adopting the supportive measures like 'Make in India'. This Campaign will help the industrialists to think of ways by which indigenous products will not only fulfill the domestic demand but also give the boost to exports.
\end{abstract}

Keywords: - Make in India, Gross Domestic Product (GDP), Indian Industrial Economy. 


\section{Methodology}

This paper has the objective to analyse the importance of 'Make in India' programme of the Indian Government in the context of industrial development. This study is based on various published and online sources and covers the Indian industrial perspective and 'Make in India' programme of the Government. Secondary data are the main sources from which necessary information have been collected for the purpose.

\section{Discussion}

India is a developing economy. The economy of India is having the eleventh rank all over the world in terms of nominal Gross Domestic product. The sustainability will in the industrial economy is urgent for achieving the stage of developed economy. Experts are having the belief that Indian Economy will attain the position of a leading industrial economy of the world up to 2020. Industries are contributing towards the GDP up to 28 percent. Industrial Policy is the prime factor for the rapid development of the economy. Developing countries require any definite industrial supportive measure for combating many evils which are affecting the development adversely. This programme is such type a measure which will be helpful in the rapid industrialization for increasing the production of both consumer as well as capital goods. The increase in the production leads to rise in the levels of living. The development process of the economy involves through industrialization. Industrialization includes the new methods of manufacturing, institutional arrangements to encourage industrial units, investment, technical and managerial skills.

For the sustainable development of the industrial sector we have to maintain as well as increase this share by adopting the supportive measures like 'Make in India'. The main aim of this programme is to generate vast employment opportunities in the country along with industrial growth. The logo of this 'Make in India' is a lion made of cogs which will certainly motivate the industrialists to manufacture more and more. This programme will be helpful to create an easy environment for the Indian industries. Business environment comprises the various internal and external factors which affects the functioning of the business.

\section{Indian Industrial Economy}

Indian economy is attaining the development at very fast rate. India has the position as one of the fastest developing nation with higher Gross Domestic Products (GDP).

Industries have attained the concept of expansion and diversification of production. The Indian economy has been agriculture based economy from the old times and its industrial sector is also based on agriculture sector. Indian industrial is very big which includes agriculture, automobiles, auto components, aviation, banking, biotechnology, cement, consumer markets, education and training, engineering, financial services, food industry, gems and jewellery, healthcare, infrastructure, insurance, information technology, manufacturing, media and entertainment, oil and gas, pharmaceuticals, real estate, research and development, retail, science and technology, semiconductor, services, steel, telecommunications, textiles, tourism and hospitality and urban market. This programme will be supportive to facilitate domestic as well as foreign invest for the industrial sector. Many multinational companies have announced their investment plans in India after announcement of this programme.

Indian micro, small and medium industries are assisting the industrial growth to the great extent. Industries are contributing towards the GDP upto28 percent. Micro, small and medium industries of India have achieved very important place by performing very well in the production, employment, exports and in terms of growth in the number of industrial units. This sector has attained more than 10 percent growth in recent years. Indian MSME industrial sector is contributing to the country's Gross Domestic Product up to 37.33 percent. This scale sector is contributing significantly in foreign trade. Indian micro, small and medium sector is responsible for just about $40 \%$ exports of the total exports of the nation.

Micro, Small and medium industries can contribute a lot in the industrial development of India. These industries can be set up with very little capital investment. These units use locally available raw material extracted from local natural resources and agricultural waste. These industrial undertakings employ many people at one place. Make in India programme will be a boon for the small industrial sector due to promotion of domestic manufacturing environment in the country.

\section{Make in India}

Make in India is the unique movement of Government of India to promote the industrial growth of the country. This campaign was launched by Prime Minister Mr. Narendra Modi on 25 September 2014. This programme includes twenty five sectors of the economy including automobile, bio-technology, aviation, construction, chemicals, electronics, electrical machinery, defense, leather, information technology, food processing, media, entertainment, mining, oil and gas, pharmaceuticals, railways, ports, roads, space, energy, textiles, thermal power, tourism and health. This programme will create a concrete base for the industrial growth in the country by enabling the industrialist to be more competent in all respects. This programme is supportive for making the country as an investment destination. Various initiatives under this programme will help the nation to attain the position of manufacturing hub. The policy initiative in this programme is very supportive for inviting both domestic and foreign investors.

The prime objective of this campaign is to make the Indian industrial sector more vibrant by facilitating domestic and foreign direct and indirect investment, nurturing innovation, increasing skills among work force, protecting intellectual property rights and creating a growth oriented manufacturing scenario. Industrialization has the prime role to play in the development of industrial economy of the underdeveloped nations. Government has recognized that the industrialization can make significant contribution in the development process. 'Make in India' is the very supportive campaign towards 
this aim. This programme will support the development process of the industries by encouraging the entrepreneurs to manufacture small and local items.

\section{Conclusion}

"Make in India" will help the industrialists to think of ways by which indigenous products will not only fulfill the domestic demand but also give the boost to exports by reducing imports so that foreign exchange may be generated for economic development. This type of procedural simplification is required for making the Indian industries competitive at the international level. This programme will enable the domestic industries to manufacture such products which will be competitive at international level. This programme aims to provide employment to 100 million people by 2022 in the manufacturing sector and this aim will be supporting to attain the sustainable industrial development in India.

\section{References}

[1].Jain T.R., Trehan Mukesh and Trehan Ranju (2016): "Business Environment”, VK Global Publications Pvt. Ltd, New Delhi.

[2].Joshi Rosy, Kapoor Sangam (2006 \& 2014): Business Environment, Kalyani Publishers, New Delhi.

[3].Cherunilam Francis (2011): International Business-Text and Cases, PHI Learning Private Limited, New Delhi.

[4].Dhingra C. Ishwar (2006): The Indian Economy-Environment and Policy, Sultan Chand \& Sons, New Delhi.

[5].Datt Ruddar Sundharam K.P.M. (2007): Indian Economy, S. Chand and Company Ltd., New Delhi.

[6].Sivayya K.V., Das V.B.M. (2004): "Indian Industrial Economy”, S. Chand \& Company Ltd., New Delhi.

[7].SINGH, Naib. Make in India Path of Growth for the Business of Indian Small Sector.

[8].International Journal of Research, [S.1.], v. 2, n. 3, p. 427-430, mar. 2015. ISSN 2348-6848. Available at: <http://edupediapublications.org/journals/index.php/IJR/article/view/1643 >.

[9].Date accessed: 27 Jan. 2016. http://www.ibef.org/industry.aspx

[10]. http://planningcommission.nic.in/data/datatable/index.php?data=datatab https://en.wikipedia.org/wiki/Make_in_India 